Canadian Science Publishing

Canadian Journal of Earth Sciences Revue canadienne des sciences de la Terre

\title{
Paleolatitudinal morpho-gradient of the early Silurian brachiopod Pentameroides in Laurentia
}

\begin{tabular}{|r|l|}
\hline Journal: & Canadian Journal of Earth Sciences \\
\hline Manuscript ID & cjes-2015-0183.R1 \\
\hline Danuscript Type: & Article \\
\hline Complete List of Authors: & $\begin{array}{l}\text { Gushulak, Cale Anthony Camille; University of Western Ontario, } \\
\text { Department of Earth Sciences } \\
\text { Jin, Jisuo; Dept of Earth Sciences, } \\
\text { Rudkin, David; Royal Ontario Museum }\end{array}$ \\
\hline Keyword: & Paleoecology, Pentameroides, Evolution, Laurentia, early Silurian \\
\hline \multicolumn{2}{|c}{} \\
\hline
\end{tabular}


1 Paleolatitudinal morpho-gradient of the early Silurian brachiopod Pentameroides in

2 Laurentia

3

4 Cale A.C. Gushulak ${ }^{1}$, Jisuo Jin ${ }^{1}$, and David M. Rudkin ${ }^{2}$

5

$6{ }^{1}$ Department of Earth Sciences, University of Western Ontario, London, Ontario, N6A 5B7,

7 Canada, cgushula@uwo.ca; jijin@uwo.ca

$82^{2}$ Department of Natural History (Palaeobiology), Royal Ontario Museum, 100 Queen's Park,

9 Toronto, Ontario M5S 2C6, Canada, davidru@rom.on.ca

10

11 Corresponding author: Cale. A.C. Gushulak (e-mail: cgushula@uwo.ca)

12

13

14

15

16

17

18

19

20

21

22

23

https://mc06.manuscriptcentral.com/cjes-pubs 
24 Paleolatitudinal morpho-gradient of the early Silurian brachiopod Pentameroides in

\section{$25 \quad$ Laurentia}

26 Cale A.C. Gushulak, Jisuo Jin, and David M. Rudkin

Abstract: Pentameroides is a large-shelled pentameride brachiopod, which was widespread throughout Laurentia in the early Silurian (Telychian). Evolving from Pentamerus in the early Telychian, it dispersed from its subtropical/high tropical origin to sub-equatorial intracratonic seas by the late Llandovery. In this study large collections of reef-dwelling Pentameroides septentrionalis from the Attawapiskat Formation, Akimiski Island, Nunavut and level-bottominhabiting Pentameroides subrectus from the Fossil Hill Formation, Manitoulin Island, Ontario, and the Jupiter Formation, Anticosti Island, Quebec, were biometrically analyzed for seven external morphological features. Bivariate and ordination analysis (PCA) revealed that $P$. septentrionalis has a more globose, more biconvex shell with a larger ventral umbo than $P$. subrectus. These morphological differences, coupled with their excellent preservation in shallow-water reefal environments, suggest that $P$. septentrionalis was adapted to a relatively

39 low-turbulence, hurricane-free, nutrient stressed environment near the equator $\left(<10^{\circ} \mathrm{S}\right)$ while $P$. subrectus lived in storm-dominated higher tropical latitudes $\left(\sim 15-25^{\circ} \mathrm{S}\right)$. This interpretation is

41 corroborated by the morphology of level-bottom-dwelling Harpidium and Sulcipentamerus from 42 the paleoequatorial lower Silurian of North Greenland, which exhibit morphological features 43 similar to those of $P$. septentrionalis even though it did not inhabit a reefal environment. PCA analysis reveals that $P$. septentrionalis resembles $P$. subrectus in early ontogeny, suggesting that P. septentrionalis evolved from $P$. subrectus as it moved northwards from high tropical to near equatorial settings. 
47 Keywords: Paleoecology, Pentameroides, Evolution, Laurentia, early Silurian

48

49

50

51

52

53

54

55

56

57

58

59

60

61

62

63

64

65

66

67

68

69

https://mc06.manuscriptcentral.com/cjes-pubs 


\section{Introduction}

Pentameroides Schuchert and Cooper, 1931 is a large-shelled pentameride brachiopod that is commonly found in the lower Silurian (Telychian) carbonate facies of Laurentia and Baltica. In modern North America, well-preserved shells of Pentameroides are abundant in the Attawapiskat Formation in the Hudson Bay lowlands of northern Ontario, Manitoba, and Nunavut (Jin et al. 1993), the Hopkinton Dolomite of Iowa (Johnson 1979), the Merriton Formation of the southern Ontario and New York (Kilgour 1963), the Fossil Hill Formation of Manitoulin Island, Ontario (Chiang 1971; Copper 1978), the upper Jupiter Formation of Anticosti Island, Quebec (Jin and Copper 2000), and the Samuelsen Høj and Hauge Bjerge formations of North Greenland (Rasmussen 2009; Fig. 1). The occurrence of Pentameroides in deep-water basinal facies is known from the upper Whittaker Formation (uppermost Telychianbasal Sheinwoodian) of Mackenzie Mountains, although this may have been in debris flow deposits derived from shallower carbonate shelf settings (Jin and Chatterton 1997).

Pentameroides evolved from Pentamerus Sowerby, 1831 during the early-middle Telychian. The mode of this speciation event has been debated, with some considering it a case of phyletic gradualism (Johnson 1979; Johnson and Colville 1982), whereas others suggest a pattern of punctuated equilibrium (Glasser 2002). In any case, Pentameroides existed alongside Pentamerus during the middle and late Telychian, showing that the origin of Pentameroides was indeed a case of cladogenesis (Glasser 2002). From the southern margin of Laurentia Pentameroides spread northwards to occupy subequatorial intracratonic basins by the latest Llandovery, with the genus comprising of at least three species: Pentameroides subrectus Hall and Clarke, 1893, Pentameroides costellata Chiang, 1971, and Pentameroides septentrionalis Whiteaves, 1904. 
This study is based on two species of Pentameroides, Pentameroides subrectus found

94 throughout the higher paleolatitudinal American mid-continent (Johnson 1979), Michigan

95 (Chiang 1971), and Anticosti basins (Jin and Copper 2000), and Pentameroides septentrionalis

96 (see Jin and Copper 1986), in the sub-equatorial Hudson Bay and Moose River basins (Jin et al.

97 1993). In addition to living at different latitudes, the two species inhabited two different shallow

98 marine environments. P. subrectus is found in storm-dominated, level-bottom environment whereas $P$. septentrionalis inhabited hurricane-free coral-stromatoporoid reefal settings (Jin et al. 1993). P. costellata is not included because it is a rare species and very few well-preserved shells are available for biometric study. In relation to Zeigler's (1965) classic level-bottom brachiopod community zones (see also Ziegler et al. 1968; Boucot 1975), Pentameroides is thought to be similar to Pentamerus (Chiang 1971; Johnson 1979); inhabiting a moderate water depth (BA 3) equivalent to a mid-shelf environment between the Eocoelia and Stricklandia community zones.

105 This zoned community structure, however, cannot be applied directly to reefal settings due to 106 high substrate heterogeneity and more complex paleoecological and paleocommunity structures 107 (Jin 2003). morphological and taphonomic characters between localities and species of Pentameroides. $P$. septentrionalis exhibits excellent preservation, with large, complete, and very thin-walled hollow 111 shells (their anterior parts being as thin as an egg shell) found commonly in apparently shallow112 water, coral-stromatoporoid reefs. This is in contrast to the micrite-infilled and broken shells of $113 P$. subrectus from higher latitude environments. In this study, specimens of $P$. septentrionalis

114 from Akimiski Island, Nunavut, and P. subrectus from Manitoulin Island, Ontario, and Anticosti 115 Island, Quebec (Fig. 2) were biometrically measured and statistically analyzed in order to 
116 identify any significant morphological differences between the species and to determine what

117 environmental factors, if any, affected the evolution of the genus.

118 Geological settings

119 Attawapiskat Formation, Akimiski Island, Hudson Bay Basin

120

121

122

123

124

125

126

127

128

129

130

131

132

133

134

135

136

137

The middle-upper Telychian Attawapiskat Formation is predominantly a succession of reefal carbonates in the Hudson Bay and Moose River basins (Sanford 1987; Suchy and Stearn 1993). The reefs are primarily built by corals and stromatoporoids and are associated with an unusually rich and diverse benthic shelly fauna dominated by brachiopods, but also including common trilobites, bivalves, gastropods, cephalopods, and ostracods (Jin et al. 1993). The reefs show 8-10 m of vertical relief in known surface exposures (Suchy 1992), but the entire formation encircles the Hudson Bay Basin and is up to 200 m thick in some locations (Sanford 1987; Suchy and Stearn 1993). During the Llandovery, the northern margin of the Hudson Bay Basin was situated over the equator (Torsvik and Cocks 2013), and the Attawapiskat Formation in the southern part of the Hudson Bay Basin and the Moose River Basin was accumulated in a subequatorial paleogeographic setting. This formation is found in outcrop on Akimiski Island, James Bay, Nunavut as well as along the Attawapiskat, Ekwan, and Severn rivers in northern Ontario. Stratigraphically, the Attawapiskat Formation is interfingered and underlain by the commonly restricted shallow-water carbonates of the Ekwan River Formation (Lavoie et al. 2014), and overlain by the evaporate-dominated Kenogami River Formation (Sanford 1987; Lavoie et al. 2014). The Attawapiskat and Ekwan River formations possess similar diagenetic qualities including the precipitation of nonferroan micrite and peloids (see Eggie et al. 2014). The overlying evaporites suggest that the Attawapiskat reefs mark the end of an early Silurian open 
138 139

marine Hudson Bay Platform and correlate with the late Telychian global regression (Haq and Schutter 2008).

The fringing and barrier coral-stromatoporoid reef complexes of the Attawapiskat Formation represent the complete recovery of the reef ecosystem after the end Ordovician mass extinction. These reefs also mark the initial stage of shelly faunal diversification associated with metazoan reefs (Chow and Stearn 1988), in addition to the moderately diverse shelly fauna of the upper Aeronian East Point reefs (Menier Formation) of Anticosti Island (Copper and Jin 2015). The Attawapiskat brachiopod faunas show excellent preservation, high alpha- and beta-diversity in the reef and inter-reef settings, and can be divided into eight associations (Jin 2002): the Lissatrypa association, the Septatrypa association, the Septatrypa-Pentameroides association, the Gypidula association, the Gotatrypa association, the Trimerella association, the Eocoelia association, and the Pentameroides association. Among these recognized brachiopod-dominated associations, several are characterized by a dominant or common component of the large-shelled Pentameroides septentrionalis. Trilobites are the only other group in the Attawapiskat Formation to have received focussed taxonomic (Norford 1981) and taphonomic (Westrop and Rudkin 1999) attention. Four distinctive associations have been recorded, but three of these primarily reflect post-mortem sorting processes of individual sclerites rather than original community composition. Each of the three taphonomic associations is known to occur with or adjacent to abundant large-shelled $P$. septentrionalis. The fourth trilobite association, comprising numerous small intact exoskeletons of several different taxa, probably represents sheltered in situ preservation of reef cavity- or crevasse-dwelling (coelobiontic) juveniles and adults.

\section{Fossil Hill Formation, Manitoulin Island, Ontario}


161 Formation in the Niagara Falls region (Brunton et al. 2009), is early-middle Telychian in age, 162 approximately 30-40 m thick (Copper 1978), and consists of thin to medium bedded, grey, richly 163 fossiliferous dolostones, with common chertified intervals (Chiang 1971, Copper 1978). It 164 overlies the thin, dolomitized and ripple-marked Mindemoya Formation and is discomformably 165 overlain by the greyish-green, argillaceous dolomicrite to wackestone Rockway Formation from 166 Manitoulin Island to Niagara Falls (Brunton et al. 2009).

On Manitoulin Island the formation is separated into three unnamed units. The lower unit 168 contains condensed beds with abundant Pentamerus. The middle unit consists of less 169 fossiliferous lime mudstone-wackestone (Brunton et al. 2009), but may have patches of large 170 favositid coral and stromatoporoid biostromes (Copper 1978; Johnson 1981). The upper unit is 171 characterized by dolomudstone and dolowackestone with abundant chert and pentameride 172 communities. Pentamerus from the lower Fossil Hill is replaced here by the very abundant 173 Pentameroides community in which P. subrectus dominates up to $95 \%$ of the community 174 (Copper 1978). This formation was likely deposited in a storm-dominated carbonate environment $175 \sim 15^{\circ}$ south of paleoequator. This is suggested by the thin lenses of pentameride shell coquina 176 found throughout the formation (Copper 1978). In addition, the shells of $P$. subrectus from this

177 formation show generally poor preservation and are often broken, disarticulated, and infilled by 178 micritic mud. 
183 (Brunton and Copper 1994; Copper and Jin 2012, 2015). The Jupiter Formation, as revised by 184 Copper and Jin (2015), is divided into four members: the Richardson, Cybele, Ferrum, and 185 Pavillon members. The lower three members comprise mainly micritic mudstone and calcareous 186 shale, in which the pentameride brachiopods are represented mainly by stricklandiids. The 187 Pavillon Member is composed of grey argillaceous micrite, wakestones, packstones, grainstones, 188 blueish-green shale, and contains abundant shell beds (Copper and Long 1990). Brachiopods are 189 190 191 192 very common in this member with abundant atrypides, athyrides, and pentamerides (Jin and Copper 2000). The top few meters of the member record the transition from Pentamerus oblongus to Pentameroides subrectus (Jin and Copper 2000; Glasser 2002).

The Jupiter Formation accumulated in the higher tropics of the early Silurian, marked by frequent storm deposits (Copper and Jin 2012, 2015). Even in the mid- to outer-shelf BA3 to BA4 settings, the Pentamerus and stricklandiid shells are often reworked, disarticulated, or truncated, and infilled by very fine micritic matrix (Jin 2008). This is true also for Pentameroides as shells in the upper Pavillon Member range from well preserved in micritic mudstone to broken 197 and disarticulated shell packstones. It is important to note, however, that $P$. subrectus does not 198 occur in the overlying Chicotte reefs and crinoid grainstone facies (Jin and Copper 2000), 199 showing that this species could not inhabit the very shallow subtidal environment in the high 200 paleotropics, unlike its slightly younger, subequatorial relative, $P$. septentrionalis, in the 201 Attawapiskat reefs.

\section{Materials and methods} Ontario Museum (Invertebrate Palaeontology) Toronto, ON) were selected for biometric analysis

205 from five collections (samples AK2, AK5, AK6, and AK8) in the Attawapiskat Formation along 
206

207

208

209

210

211

212

213

214

215

216

217

218

219

220

221

222

223

224

225

226

227

228

the north shore of Akimiski Island, Nunavut. Each of the five collections contributed 59, 53, 52, 53, and 105 specimens respectively, making up a total of 322 specimens. These shells are often found in life position, associated with large framework-building tabulate corals and stromatoporoids of the reef. Disarticulation is relatively rare and most shells are found intact and often hollow with only a thin layer of isopachous calcitic cement lining the interior (Fig 4: A, B).

Well-preserved shells representing a complete ontogenetic sequence of this species can be observed, from very small $(<10 \mathrm{~mm})$ juvenile to very large $(>65 \mathrm{~mm})$ forms. The large mature shells from this formation often show asymmetrical and distorted shapes as a consequence of growing in tightly crowded clusters. These clusters generally occur in depressions within the reef between the large favositid corals where young shells could grow before being compressed and deformed by other surrounding shells (Jin 2002).

Specimens of P. subrectus from the Fossil Hill Formation of Manitoulin Island, Ontario (Fig. 5) were also selected for measurement in this study. Although the samples are dominated by incomplete shells, well-preserved whole shells from two collections (M25 and M26) were selected for analysis. These two subsets consisted of 39 and 36 specimens respectively, amounting to a total of 75 specimens. One small collection containing six specimens of $P$. subrectus from the Jupiter Formation of Anticosti Island, Quebec was also used for this study. The shells from these localities are more poorly preserved than those from Akimiski Island and are often broken, deformed (particularly in the transverse plane), and filled by a fine grained micritic matrix (Fig 4: C, D). This poorer preservation results in the relatively small size of the Manitoulin and Anticosti collections compared to the Akimiski Island collection.

A total of 403 specimens were measured using a pair of electronic calipers for the following characteristics: total shell length, ventral umbonal height, length from the dorsal apex 
229 to the ventral umbo, the total shell width, the total shell thickness, the thickness of the ventral

230 valve, and the thickness of the dorsal valve (Fig. 6). Three morphology indices were also

231 developed and utilized in the statistical comparison between the two species. The indices are as

232 follows:

233

234

235

236

237

238

T/W: Thickness/width, proxy for globosity — a higher value means a more globose shell;

U/L: Ventral umbonal height/ length, proxy for the size of the ventral umbo compared

to the total shell — higher values indicate a large umbo and larger umbonal shell proportion;

Td/Tv: Dorsal valve thickness/Ventral valve thickness, proxy for biconvexity —

higher values indicate a more convex shell.

The dataset derived from the measurements was analyzed statistically using the PAST

Software Package v 3.08 (Hammer et al. 2001; Hammer and Harper 2006.) in several linear

241 regression comparisons between the different collections and species. Principal components

242 analysis (PCA) was also performed to create a scatter plot to detect possible ordination or trends

243 of morphological changes.

244 Results

Statistical analyses of the biometric measurements revealed several morphological trends

246 among the collections of $P$. septentrionalis and P. subrectus. All slopes from linear regressions

247 of the discovered trends as well as their associated standard errors are shown together in Table

248 1A. Based on these values, t-tests were performed on the slopes for each comparison to

249 determine if the results are statistically significant. It was found that the differences in slopes

250 represent statistically different results at a 95\% confidence interval in all cases (Table 1B). 
251

252

253

254

255

256

257

258

259

260

261

262

263

264

265

266

267

268

269

270

271

\section{Shell size and globosity}

The shells of $P$. septentrionalis tend to be much larger and more globose (total shell width compared to total shell thickness) than those of $P$. subrectus (Table 2). Maximum widths and thicknesses of the three groups clearly show the size differences between $P$. septentrionalis (maximum width $=68.1 \mathrm{~mm}$, thickness $=46.8 \mathrm{~mm}), P$. subrectus of Manitoulin Island $(\max$. width $=45.0 \mathrm{~mm}$; thickness $=33.8 \mathrm{~mm})$, and $P$. subrectus of Anticosti Island $($ max. width $=48.0$ $\mathrm{mm}$; thickness $=20.7 \mathrm{~mm})$. The two species also show a clear difference in the linear regression comparison of these features (slope of $P$. septentrionalis $=0.58$; slope of $P$. subrectus $=0.41$; Fig. 7).

\section{Ventral umbonal height compared to total shell length}

The ventral umbones of $P$. septentrionalis are generally high, with an average umbonal height of $7.6 \mathrm{~mm}(\max =20.0 \mathrm{~mm})$. This character contrasts with the smaller umbones of $P$. subrectus from Manitoulin Island (average $=6.0 \mathrm{~mm}, \max .=11.4 \mathrm{~mm}$ ) and Anticosti Island (average $=4.6 \mathrm{~mm}, \max .=6.6 \mathrm{~mm})$. When compared to the total shell length, the ventral umbones of $P$. septentrionalis take up a larger proportion of the shell than the umbones of $P$. subrectus (Table 3). This trend is shown graphically in Figure 8 with P. septentrionalis having a slope of 0.25 and P. subrectus having a slope of 0.14 .

\section{Dorsal valve thickness vs. ventral valve thickness (depth)}

A third morphological difference lies in the ratio between the thicknesses (depth) of the two valves between the species. The average dorsal to ventral valve depth ratio is 0.76 for $P$. septentrionalis, compared to 0.68 for P. subrectus. This difference is less pronounced than the 
272 other relationships but is still significantly different (Table 1B) in the linear regressions (Fig. 9).

273 The slope of the regression of $P$. septentrionalis is 0.67 while the slope of $P$. subrectus is 0.52 .

274 Principal components analysis (PCA)

275

276

277

278

279

280

281

282

283

284

285

286

287

PCA yielded a distinct grouping pattern based on 403 specimens and 7 biometric

variables (see Methods). Due to the large number of well-preserved P. septentrionalis samples, including juvenile shells, the ontogenetic variation of $P$. septentrionalis can be seen in its widespread data points. In this analysis Component 1 accounted for $\sim 77 \%$ of the variance with Component 2 accounting for $\sim 11 \%$ of the total variance within the sample. This suggests that the PCA yielded distinct principal components, which are statistically representative of the variation observed between the two Pentameroides species. Three groups were identifiable in the PCA plot (Fig. 10); Group A represents very small juvenile shells of $P$. septentrionalis as well as an outlying small specimen of $P$. subrectus from Manitoulin Island, Group B contains the majority of $P$. subrectus from both localities and the mid-sized specimens of $P$. septentrionalis, and Group $\mathrm{C}$ consists of the large to giant sized specimens of $P$. septentrionalis and large outlying specimens of $P$. subrectus.

\section{Discussions}

\section{Morphology and implications for paleoecology and evolution}

The large samples of well-preserved $P$. septentrionalis shells made it possible to examine a fairly complete ontogenetic sequence using multivariate analysis. In the PCA plot (Fig. 10), Groups A and B show that juvenile specimens of this species cluster closely with the majority of the adult specimens of $P$. subrectus before diverging into their derived adult morphology in

Group C. It appears that $P$. subrectus maintains its lenticular morphology, only increasing in 
294 size, throughout ontogeny (Fig. 5), whereas $P$. septentrionalis diverges into its more globular and 295 biconvex adult morphology in late ontogeny (Figs. 7, 8, 9). The ontogenetic transformation of $P$. 296 septentrionalis shell morphology is so drastic that the equibiconvex shells in early ontogeny 297 were originally classified in a separate genus and species, Meristina expansa Whiteaves, 1904 298 before being revised (see Jin and Copper 1986). The similarities in early ontogeny between $P$. 299 subrectus and $P$. septentrionalis, combined with the first appearance datum (FAD) (P. subrectus 300 in the middle Telychian; P. septentrionalis in the late Telychian) strongly suggest that $P$. 301 302

septentrionalis evolved from $P$. subrectus during the middle to late Telychian as the genus migrated from higher to mid-tropics to equatorial settings.

The adult of morphology of $P$. septentrionalis (Fig. 3 A-E) likely evolved as a mechanism to improve energy efficiency in the shallow water reefal environment it inhabited. The globular shell shape and increased convexity would allow for the organism to house larger lophophores and therefore improve feeding and respiratory efficiency. The large ventral umbones of the adult specimens reflect a change in life position throughout ontogeny. Like most pentamerides, Pentameroides did not have a functioning pedicle to anchor itself to the substrate. They instead maintained their posterior-down life position by crowding and thickening the shell walls of their posteriors (Ziegler 1966). The large reef-dwelling P. septentrionalis expanded on this life strategy by enlarging their ventral valves and umbones and changed from an erect or sub-erect life position in early ontogeny to a recumbent orientation in late ontogeny. This enabled the growth of a deeper and largely immobile ventral valve to accommodate larger lophophores (projected from a relatively small dorsal valve, to which the lophophores are attached) to improve feeding/respiratory efficiency. It would also reduce metabolic energy output, requiring only the small and thin dorsal valve to be mobilized for opening and closing the 
317 shell. This type of life position and morphology also occurs in the level-bottom-dwelling

318 Sulcipentamerus and Harpidium of the paleoequatorial lower Silurian Washington Land Group 319 of North Greenland (Fig. 1; Jin et al. 2009). In these taxa the morphology is more extreme than 320 in P. septentrionalis as the ventral valve has deepened into a horn like structure with the dorsal 321 valve sitting atop as a 'lid' (Fig. 11). It is important to note that these taxa inhabited a level322 bottom environment while $P$. septentrionalis inhabited a reefal environment, indicating that this 323 morphology was independent of ecological guild types.

It should also be noted that the North Greenland pentamerides evolved into this derived morphology in the level-bottom ecosystem, but $P$. subrectus, which also inhabited level-bottom environments, retained its vertical life position like Pentamerus (Jin 2008). As shown in the PCA

327 plot (Fig. 10), P. subrectus maintains a lenticular, nearly equibiconvex shell shape throughout ontogeny while $P$. septentrionalis become globular and more ventribiconvex in gerontic forms.

329 A possible explanation is that high frequency of severe storms in the mid- to higher paleotropics 330 (such as the Michigan and Anticosti basins) prevented P. subrectus from evolving a recumbent 331 life position because a relatively deep, immobile ventral valve in such a position would be 332 susceptible to smothering by mud during storms. A shell vertically oriented on the substrate 333 would be much more efficient for shedding storm-deposited mud when the two valves are open. 334 A high energy environment would provide sufficient oxygenation and nutrient supply so that the 335 selection pressure for larger lophophores would be much reduced for $P$. subrectus compared to 336 P. septentrionalis.

\section{Taphonomy and paleoenvironmental interpretations}

The differences in morphology and taphonomy between the two species of 
340 inhabited. It has been shown by Jin et al. (2013) that, in the Ordovician and Silurian, Laurentia

341 featured a hurricane-free zone approximately $10^{\circ}$ north and south of the equator, similar to that

342 of the modern near-equatorial tropics. Paleogeographically, the Michigan and Anticosti Basins

343 were $15-25^{\circ}$ south while the Hudson Bay region was within $10^{\circ}$ of the equator (Fig. 1; Torsvik

344 and Cocks 2013). This suggests that the Attawapiskat coral-stromatoporoid reefal environments

345 experienced very few severe storms which allowed $P$. septentrionalis to evolve a larger, globular

346 shell, with a proportionally larger and deeper recumbent ventral valve, resulting in a recumbent

347 living position in gerontic forms (Fig. 10 Group C).

This interpretation finds support in the taphonomic characters of $P$. septentrionalis in the

349 Attawapiskat Formation, especially the common preservation of larger, thin-walled, hollow

350 shells in a shallow water reefal setting (Fig. 4 A, B). This type of preservation could not have

351 occurred in an environment subjected to frequent, hurricane-grade storms. The shells of $P$.

352 subrectus from the higher tropics, however, do signify a storm-dominated environment as they

353 are often broken, disarticulated, deformed, and infilled with micritic matrix (Fig. 4 C, D). These

354 taphonomic features are even more significant when depth of water is taken into account. The

355 level-bottom P. subrectus dominated communities likely inhabited a mid to outer shelf (BA

356 3/BA 4) depth and were subjected to powerful storms while the much shallower Attawapiskat

357 reefal settings experienced insignificant storm damage (Fig. 12). These taphonomic differences

358 indicate that storm frequency and therefore paleolatitudinal position were major factors

359 influencing the derivation of $P$. septentrionalis from P. subrectus. 
1. Principal component analysis shows that Pentameroides septentrionalis resembles $P$. subrectus at early growth stage but diverges in morphology during late ontogeny, indicating that Pentameroides septentrionalis evolved from P. subrectus.

2. Morphological characteristics of $P$. septentrionalis (increased globosity and convexity, larger ventral valve and umbo) are adaptations to increase energy efficiency living in a hurricane-free, but nutrient-stressed environment. This change in morphology is maximized in the Harpidium and Sulcipentamerus shells of paleoequatorial North Greenland.

3. A change from vertical ( $P$. subrectus) to recumbent (P. septentrionalis) life position was related to reduced need for mud-shedding in a depositional setting that lacked hurricane grade storms.

4. Excellent preservation of large, egg-thin shells of $P$. septentrionalis in the shallow-water reefal facies of the Attawapiskat Formation indicates a hurricane free near-equatorial paleoenvironment, whereas poorly preserved shell of $P$. subrectus from Manitoulin and Anticosti islands suggest high tropical storm-dominated environments.

\section{Acknowledgements}

Paul Copper kindly made available his collection of Pentameroides from Manitoulin Island for this study. The Nunavut government facilitated this research project by permitting fossil collection on Akimiski Island. Funding for this study was provided by the Natural Science and Engineering Research Council of Canada (Jin), The Royal Ontario Museum, and the National Geographic Society (Grant No. 7300-02 to Rudkin). This paper is a contribution to IGCP Project 591: The Lower to Middle Paleozoic Revolution. 
384

385

386

387

388

389

390

391

392

393

394

395

396

397

398

399

400

401

402

403

404

405

406

\section{References}

Boucot, A.J. 1975. Evolution and extinction rate controls. Elsevier, New York, N.Y.

Brunton, F. R., and Copper, P. 1994. Paleoecologic, temporal, and spatial analysis of early Silurian reefs of the Chicotte Formation, Anticosti Island, Quebec, Canada. Facies, 31: 57-79.

Brunton, F. R., Turner, E., and Armstrong, D. 2009. A guide to the Paleozoic geology and fossils of Manitoulin Island and northern Bruce Peninsula, Ontario, Canada. Canadian Paleontology Conference Field Trip Guidebook, 14.

Chiang, K. K. 1971. Silurian pentameracean brachiopods of the Fossil Hill Formation, Ontario. Journal of Paleontology, 45: 849-861.

Chow, A. M., and Stearn, C. W. 1988. Attawapiskat patch reefs, Lower Silurian, Hudson Bay Lowlands, Ontario. Canadian Society of Petroleum Geologists Memoir, 13: 273-270.

Copper, P. 1978. Paleoenvironments and paleocommunities in the Ordovician-Silurian sequence of Manitoulin Island. Michigan Basin Geological Society Special Papers, 3: 47-61.

Copper, P., and Long, D. G. F. 1990. Stratigraphic revision of the Jupiter Formation, Anticosti Island, Canada: a major reference section above the Ordovician-Silurian boundary. Newsletters on Stratigraphy, 23: 11-36.

Copper, P., and Jin, J. 2012. Early Silurian (Aeronian) East Point coral patch reefs of Anticosti Island, Eastern Canada: first reef recovery from the Ordovician/Silurian mass extinction in eastern Laurentia. Geosciences, 2: 64-89.

Copper, P. and Jin, J. 2015. Tracking the early Silurian post-extinction faunal recovery in the Jupiter Formation of Anticosti Island, eastern Canada: A stratigraphic revision. Newsletters on Stratigraphy, 48(2): 221-240. 
407 Eggie, L.A., Pietrus, E., Ramdoyal, A. and Chow, N. 2014. Diagenesis of the Lower Silurian 408 Ekwan River and Attawapiskat formations, Hudson Bay Lowland, northern Manitoba 409 410

Haq, B. U., and Schutter S. R. 2008. A chronology of Paleozoic sea level changes. Science, 322:

Hammer, Ø., Harper, D.A.T., Ryan, P. 2001. PAST: Paleontological statistics software package for education and data analysis. Palaeontologia Electronica 4(1).

Hall, J., and Clarke, J.M. 1893. An introduction to the study of the genera of Palaeozoic Brachiopoda. New York State Geological Survey, Palaeontology of New York, 8: 1-317.

Hammer, Ø., Harper, D.A.T. 2006. Paleontological Data Analysis. Blackwell Publishing, Malden, Massachusetts. $64-68$.

Glasser, P. M. 2002. Mode of evolution in the early Silurian Pentamerus-Pentameroides lineage, Anticosti Island, Quebec. M.Sc. thesis, Department of Earth Sciences, The University of Western Ontario, London, Ontario.

Jin, J. 2002. Niche partitioning of reef-dwelling brachiopod communities in the Lower Silurian Attawapiskat Formation, Hudson Bay Basin, Canada. IPC 2002, Geological Society of Australia, Abstracts No. 68, 83-84.

425 Jin. J. 2003. The Early Silurian Brachiopod Eocoelia from the Hudson Bay Basin, Canada. Palaeontology, 46: 885-902. 
427 Jin, J. 2008. Environmental control on temporal and spatial differentiation of Early Silurian

428

429

430

431

432

433

434

435

436

437

438

439

440

441

442

443

444

445

446

447

448

449

pentameride brachiopod communities, Anticosti Island, eastern Canada. Canadian

Journal of Earth Sciences, 45: 159-187.

Jin, J., and Copper, P. 1986. The Early Silurian Brachiopod Pentameroides from the Hudson Bay Lowlands, Ontario. Canadian Journal of Earth Sciences, 23: 1309-1317.

Jin, J., and Chatterton, B.D.E. 1997. Latest Ordovician-Silurian articulate brachiopods and biostratigraphy of the Avalanche Lake area, southwestern District of Mackenzie. Palaeontographica Canadiana, 13: 1-167.

Jin, J., and Copper, P. 2000. Late Ordovician and Early Silurian pentamerid brachiopods from Anticosti Island, Québec, Canada. Palaeontographica Canadiana, 18: 1-140.

Jin, J., Caldwell, W.G.E., and Norford, B.S. 1993. Early Silurian brachiopods and biostratigraphy of the Hudson Bay lowlands, Manitoba, Ontario, and Quebec. Geological Survey of Canada Bulletin, 457.

Jin, J., Harper, D. A., and Rasmussen, C. M. Ø. 2009. Sulcipentamerus (Pentamerida, Brachiopoda) from the Lower Silurian Washington Land Group, North Greenland. Palaeontology, 52: 385-399.

Jin, J., Harper, D. A. T., Cocks, L. R. M., McCausland, P. J. A., Rasmussen, C. M. Ø ., and Sheehan, P. M. 2013. Precisely locating the Ordovician equator in Laurentia. Geology, 41: $107-110$.

Johnson, M. E. 1979. Evolutionary brachiopod lineages from the Llandovery series of eastern Iowa. Paleontology, 22: 549-567.

Johnson, M. E. 1981. Correlation of Lower Silurian strata from the Michigan Upper Peninsula to Manitoulin Island. Canadian Journal of Earth Sciences, 18: 896-883. 
450 Johnson, M. E., and Colville, V. R. 1982. Regional integration of evidence for evolution in the 451 Silurian Pentamerus-Pentameroides lineage. Lethaia, 15: 41-54.

452 Kilgour, W. J. 1963. Lower Clinton (Silurian) relationships in western New York and Ontario. 453 Geological Society of America Bulletin, 74: 1127-1142.

454 Lavoie, D., Armstrong, D., Nicolas, M., and Zhang, S. 2015. Report of activities for the Hudson 455 Platform: stratigraphic and source rock research, Ontario, Manitoba and Nunavut. Geological Survey of Canada, Open File 7713. doi: 10.4095/295547.

Norford, B.S. 1981. The trilobite fauna of the Silurian Attawapiskat Formation, northern Ontario and northern Manitoba. Geological Survey of Canada Bulletin, 327.

Rassmussen, C. M. Ø. 2009. A paleoecological and biogeographical investigation of the Ordovician-Silurian boundary based on brachiopods. Ph. D. Thesis, Department of Geosciences and Natural Resource Management, University of Copenhagen, Copenhagen, Denmark.

Sanford, B. V. 1987. Paleozoic geology of the Hudson platform. Canadian Society of Petroleum Geologists Memoir, 12: 483-505.

Schuchert, C., and Cooper, G. A. 1931. Synopsis of the brachiopod genera of the suborders Orthoidea and Pentameroidea, with notes on the Telotremata. American Journal of Science, 20: 241-251.

Sowerby, J. de C., 1839. Organic remains. In The Silurian System. Edited by R.I Murchison. John Murray, London, pp. 579-765.

Suchy, D. R. 1992. Hudson Bay Platform: Silurian sequence stratigraphy and palaeoenvironments. Ph. D. thesis, Department of Geological Sciences, McGill

472 University, Montreal, Québec. 
473 Suchy, D. R., and Stearn, C. W. 1993. Lower Silurian reefs and post-reef beds of the

474

475

476

477

478

479

480

481

482

483

484

485

486

487

488

489

490

491

492

493

494

91 Attawapiskat Formation, Hudson Bay Platform, northern Ontario. Canadian Journal of Earth Sciences, 30: 575-590.

Torsvik, T.H., and Cocks, L.R.M. 2013. New global paleogeographical reconstructions for the early Paleozoic and their generation. Geological Society London Memoirs, 38: 5-24.

Westrop, S.R., and Rudkin, D.M. 1999. Trilobite taphonomy of a Silurian reef: Attawapiskat Formation, northern Ontario. Palaios, 14: 389-397.

Whiteaves, J. F. 1904. Preliminary list of fossils from the Silurian (Upper Silurian) rocks of the Ekwan River and Sutton Mill Lakes, Keewatin, collected by D. B. Dowling in 1901 with descriptions of such species as appear to be new. Geological Survey of Canada, Annual Report, 14: 38-59.

Zeigler, A. M. 1965. Silurian marine communities and their environmental significance. Nature, 207: $270-272$.

Zeigler, A. M., Boucot, A. J., and Sheldon, R. P. 1966. Silurian pentamerid brachiopods preserved in position of growth. Journal of Paleontology, 40: 1032-1036.

Zeigler, A. M., Cocks, L. R. M., and Bambach, R. K. 1968. The composition and structure of lower Silurian marine communities. Lethaia, 1: 1-27. 
495 Table 1. A) List of slope and standard error values for each of the morphological character linear

496 regression comparisons. B) Statistical t-Tests for each comparison.

\begin{tabular}{|c|c|c|c|c|}
\hline $\begin{array}{l}\text { A) } \\
\text { Morphology Comparison }\end{array}$ & Slopes & & Standard Errors & \\
\hline & $\begin{array}{l}P . \\
\text { septentrionalis }\end{array}$ & $\begin{array}{l}P . \\
\text { subrectus }\end{array}$ & $\begin{array}{l}P . \\
\text { septentrionalis }\end{array}$ & $\begin{array}{l}P . \\
\text { subrectus }\end{array}$ \\
\hline Shell Thickness v. Shell Width & 0.58348 & 0.41369 & 0.023744 & 0.047881 \\
\hline Umbonal Height v. Shell Length & 0.24953 & 0.14285 & 0.012661 & 0.014602 \\
\hline $\begin{array}{l}\text { Dorsal Thickness v. Ventral } \\
\text { Thickness }\end{array}$ & 0.67324 & 0.51835 & 0.026515 & 0.065183 \\
\hline
\end{tabular}

497

B)

$\begin{array}{lllll}\text { t-Test }(0.95 \text { confidence) } & \text { t- value } & \text { d.f. } & \text { p- value } & \text { Conclusion }\end{array}$

\begin{tabular}{lcccl}
\hline Shell Thickness v. Shell Width & 3.17691103 & 399 & 0.00160433 & $\begin{array}{l}\text { Statistically } \\
\text { different }\end{array}$ \\
\hline Umbonal Height v. Shell Length & 5.51983974 & 399 & $6.00 \mathrm{E}-08$ & $\begin{array}{l}\text { Statistically } \\
\text { different }\end{array}$ \\
\hline $\begin{array}{l}\text { Dorsal Thickness v. Ventral } \\
\text { Thickness }\end{array}$ & 2.20109516 & 399 & 0.02830133 & $\begin{array}{l}\text { Statistically } \\
\text { different }\end{array}$ \\
\hline
\end{tabular}

498

499

500

501

502

503

504

505

506 
507 Table 2. Maximum and minimum values $(\mathrm{mm})$ of total shell length, total shell width, and total

508 shell thickness for the three collections.

\begin{tabular}{lllllll}
\hline & $\begin{array}{l}\text { Maximum } \\
\text { Length }\end{array}$ & $\begin{array}{l}\text { Minimum } \\
\text { Length }\end{array}$ & $\begin{array}{l}\text { Maximum } \\
\text { Width }\end{array}$ & $\begin{array}{l}\text { Minimum } \\
\text { Width }\end{array}$ & $\begin{array}{l}\text { Maximum } \\
\text { Thickness }\end{array}$ & $\begin{array}{l}\text { Minimum } \\
\text { Thickness }\end{array}$ \\
\hline $\begin{array}{l}P . \\
\text { septentrionalis }\end{array}$ & 66.4 & 7.7 & 68.1 & 6.9 & 46.8 & 5.2 \\
\hline $\begin{array}{l}P \text {. subrectus- } \\
\text { Manitoulin }\end{array}$ & 64.5 & 13.6 & 45.0 & 12.5 & 33.8 & 8.6 \\
Island & & & & & & \\
\hline $\begin{array}{l}P \text { subrectus- } \\
\text { Anticosti }\end{array}$ & $\begin{array}{l}\text { N/A (broken } \\
\text { Island }\end{array}$ & 27.1 & 48.0 & 27.3 & 20.7 & 13.8 \\
\hline
\end{tabular}

509

510

511

512

513

514

515

516

517

518

519

520

521

522

523

524 
525 Table 3. Maximum, minimum, and average ventral umbo lengths ( $\mathrm{mm}$ ) and average proportion 526 of ventral umbo to total shell length for the three collections.

\begin{tabular}{lllll}
\hline & $\begin{array}{l}\text { Maximum } \\
\text { Ventral } \\
\text { Umbo Length }\end{array}$ & $\begin{array}{l}\text { Minimum } \\
\text { Ventral } \\
\text { Umbo Length }\end{array}$ & $\begin{array}{l}\text { Average } \\
\text { Ventral } \\
\text { Umbo Length }\end{array}$ & $\begin{array}{l}\text { Average Proportion of Total } \\
\text { Shell Length }\end{array}$ \\
\hline $\begin{array}{l}P . \\
\text { septentrionalis }\end{array}$ & 20.0 & 1.0 & 7.6 & $19.8 \%$ \\
\hline $\begin{array}{l}P \text {. subrectus- } \\
\text { Manitoulin }\end{array}$ & 11.4 & 2.3 & 6.0 & $18.4 \%$ \\
Island & & & & $12.4 \%$ \\
\hline $\begin{array}{l}P \text { subrectus- } \\
\text { Anticosti }\end{array}$ & 6.6 & 2.8 & 4.6 & \\
Island & & & & \\
\hline
\end{tabular}




\section{$544 \quad$ Figure Captions}

545 Fig. 1. Map of Laurentia, Baltica, and Avalonia in the late Telychian (430 Ma). Thickened lines 546 indicate boundaries of the paleoplates. Squares denote locations of Pentameroides subrectus: 1. 547 Jupiter Formation, Anticosti Island, Quebec; 2. Merriton Formation, Southern Ontario and New

548 York; 3. Fossil Hill Formation, Manitoulin Island, Ontario; 4. Hopkinton Dolomite, Iowa.

549 Circles indicate locations of Pentameroides septentrionalis; 5. Attawapiskat Formation, Hudson

550 Bay and Moose River Basins; 6, 7, 8. Samuelsen Høj and Hauge Bjerge formations, North

551 Greenland. Star denotes location of Harpidium and Sulcipentamerus Washington Land Group,

552 North Greenland. Based on Torsvik and Cock's (2013) paleogeography.

553 Fig. 2. Map of modern eastern Canada showing study areas.

554 Fig. 3. Pentameroides septentrionalis, Attawapiskat Formation, Akimiski Island, Nunavut. A-E:

555 Specimen ROM 63693 late ontogeny, dorsal, ventral, lateral, posterior, and anterior views. F-J:

556 Specimen ROM 63694 early ontogeny, dorsal, ventral, lateral, posterior, and anterior views. K-

557 O: Specimen ROM 63695 transitioning morphology, dorsal, ventral, lateral, posterior, and 558 anterior views. Scale bars are $1 \mathrm{~cm}$.

559 Fig. 4. Differing taphonomies of $P$. septentrionalis (A/B) and P. subrectus (C/D). Note the egg560 thin shell and isopachous cement filling in A/B and the broken and infilled shell of C/D. Scale 561 bars are $1 \mathrm{~cm}$. Arrows mark the interiors of the shells. Specimen A: ROM 63696, Specimen B: 562 ROM 63697, Specimen C/D: A1395.

563 Fig. 5. Pentameroides subrectus, Fossil Hill Formation, Manitoulin Island, Ontario. A-E:

564 Specimen M25-2 dorsal, ventral, lateral, posterior, and anterior views. F-J: Specimen M25-43

565 dorsal, ventral, lateral, posterior, and anterior views. Scale bars are $1 \mathrm{~cm}$.

566 Fig. 6. External morphological characters measured in this study. 
567 Fig. 7. Plot comparing globosity (total shell width vs total shell thickness) of $P$. septentrionalis 568 and P. subrectus.

569 Fig. 8. Plot comparing ventral umbo length to total shell length of $P$. septentrionalis and $P$. 570 subrectus.

571 Fig. 9. Plot comparing biconvexity (dorsal valve thickness vs ventral valve thickness) of $P$.

572 septentrionalis and P. subrectus.

573 Fig. 10. PCA plot showing distribution of the three collections. Group A: juvenile $P$.

574 septentrionalis and outlying small P. subrectus from Manitoulin Island; Group B: mid- sized $P$.

575 septentrionalis and adult P. subrectus; Group C: large sized P. septentrionalis and outlying large

576 P. subrectus from Manitoulin Island.

577 Fig. 11. The interpreted life positions of: P. subrectus in high tropical level-bottom environments 578 (A/A1), P. septentrionalis in low tropical reefal environments (B/B1), and Harpidium and 579 Sulcipentamerus in equatorial level-bottom environments $(\mathrm{C} / \mathrm{C} 1)$. Note the transition in life 580 position from vertical (P. subrectus) to recumbent ( $P$. septentrionalis and 581 Harpidium/Sulcipentamerus) as latitude decreases.

582 Fig. 12. Comparison between environments of low tropical reef environment and high tropical 583 storm-dominated level-bottom communities. Differences in water depth habitation and 584 taphonomy are shown in the reconstructed shell beds. 


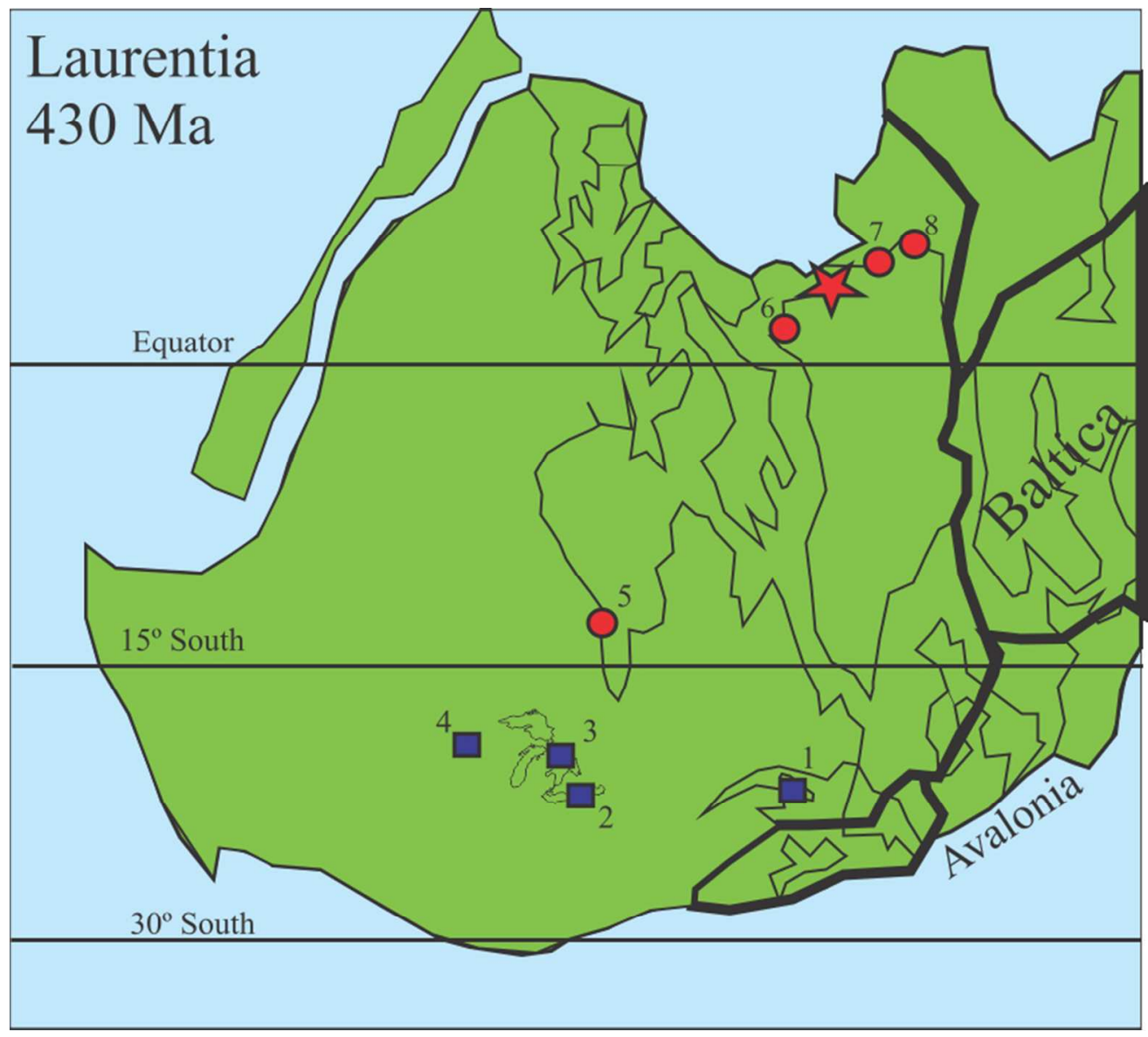

Fig. 1. Map of Laurentia, Baltica, and Avalonia in the late Telychian (430 Ma). Thickened lines indicate boundaries of the paleoplates. Squares denote locations of Pentameroides subrectus: 1. Jupiter Formation, Anticosti Island, Quebec; 2. Merriton Formation, Southern Ontario and New York; 3. Fossil Hill Formation, Manitoulin Island, Ontario; 4. Hopkinton Dolomite, Iowa. Circles indicate locations of Pentameroides septentrionalis; 5. Attawapiskat Formation, Hudson Bay and Moose River Basins; 6, 7, 8. Samuelsen Høj and Hauge Bjerge formations, North Greenland. Star denotes location of Harpidium and Sulcipentamerus Washington Land Group, North Greenland. Based on Torsvik and Cock's (2013) paleogeography. 


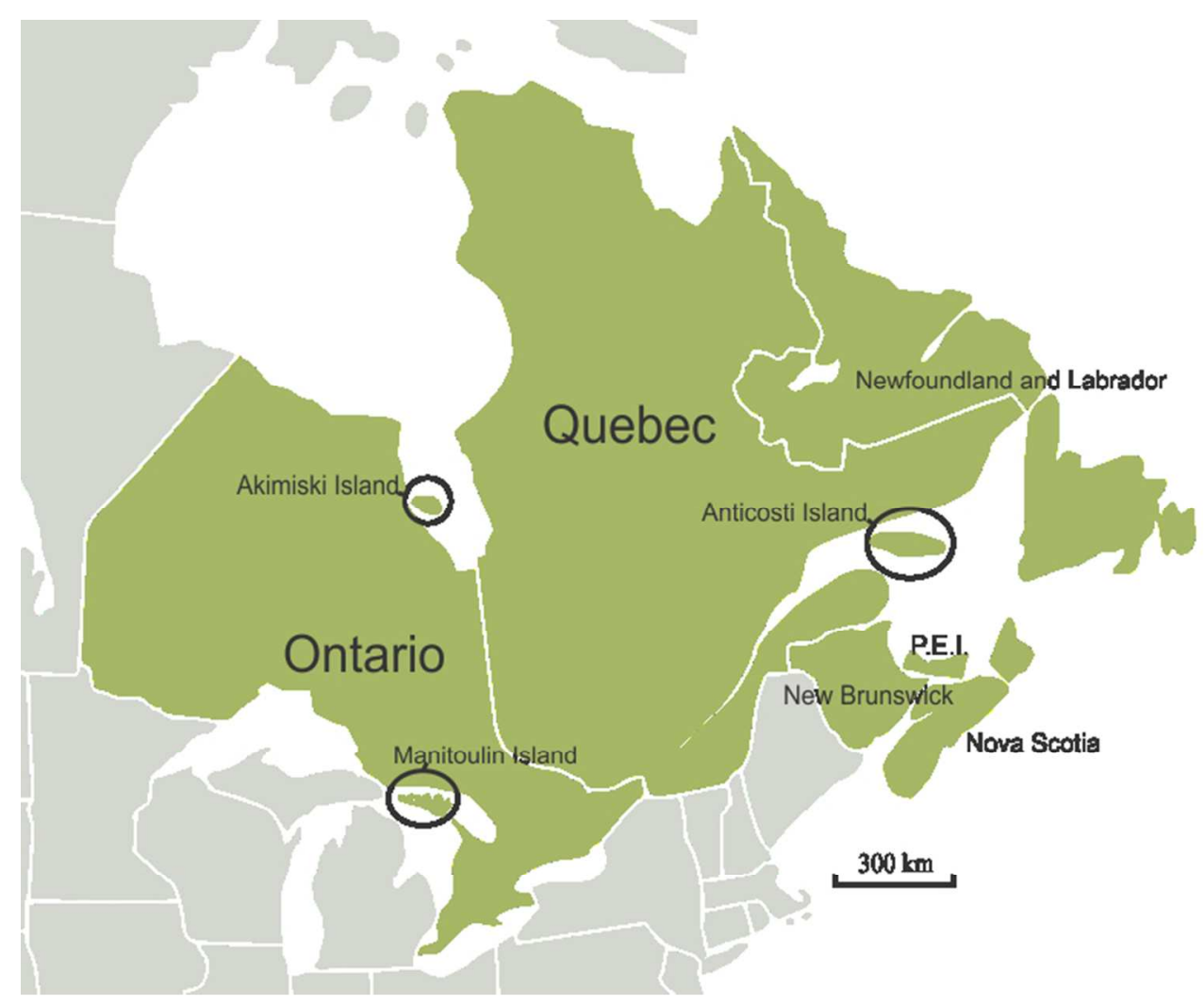

Fig. 2. Map of modern eastern Canada showing study areas. 

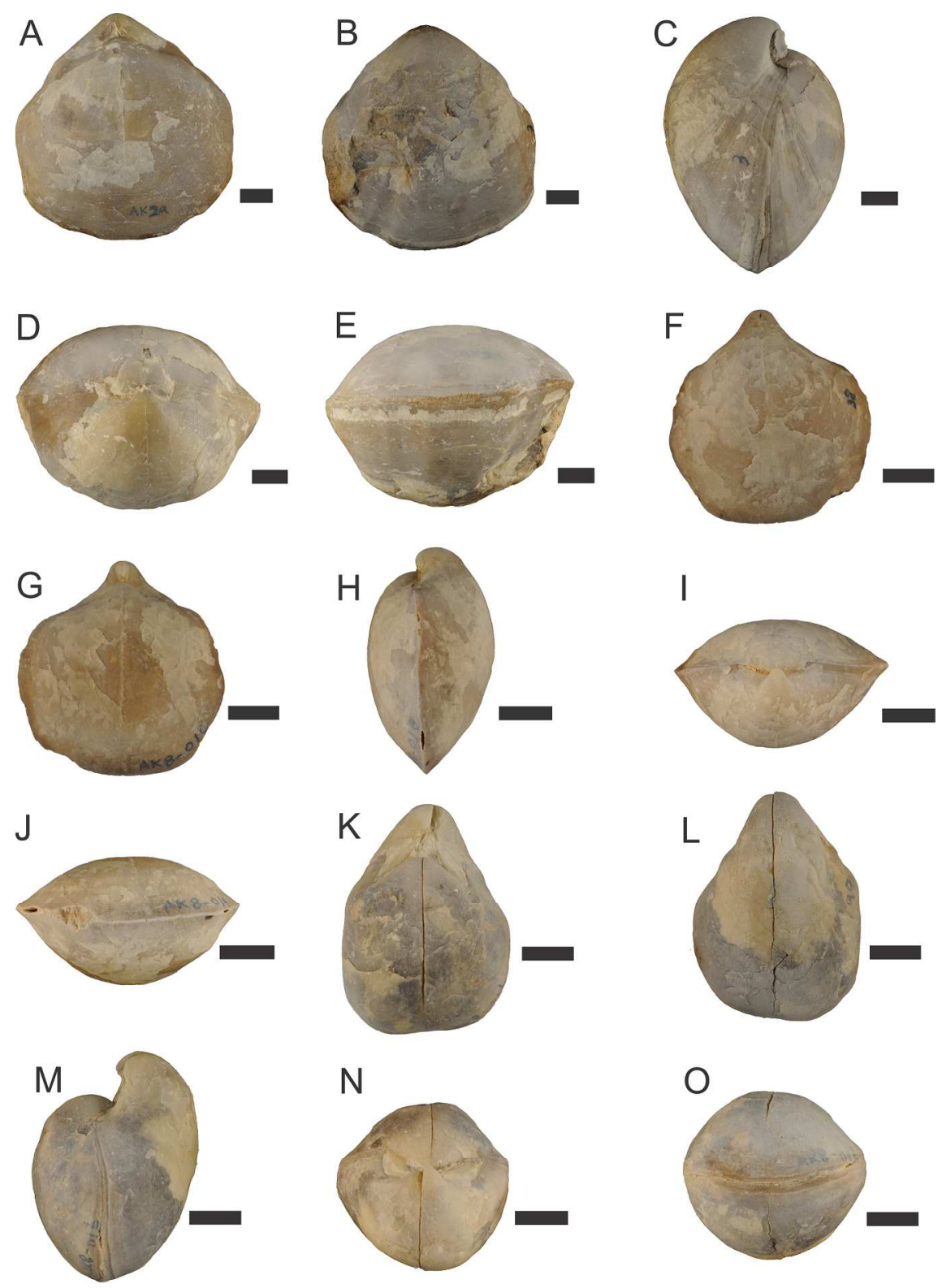

Fig. 3. Pentameroides septentrionalis, Attawapiskat Formation, Akimiski Island, Nunavut. A-E: Specimen ROM 63693 late ontogeny, dorsal, ventral, lateral, posterior, and anterior views. F-J: Specimen ROM 63694 early ontogeny, dorsal, ventral, lateral, posterior, and anterior views. K-O: Specimen ROM 63695 transitioning morphology, dorsal, ventral, lateral, posterior, and anterior views. Scale bars are $1 \mathrm{~cm}$. 

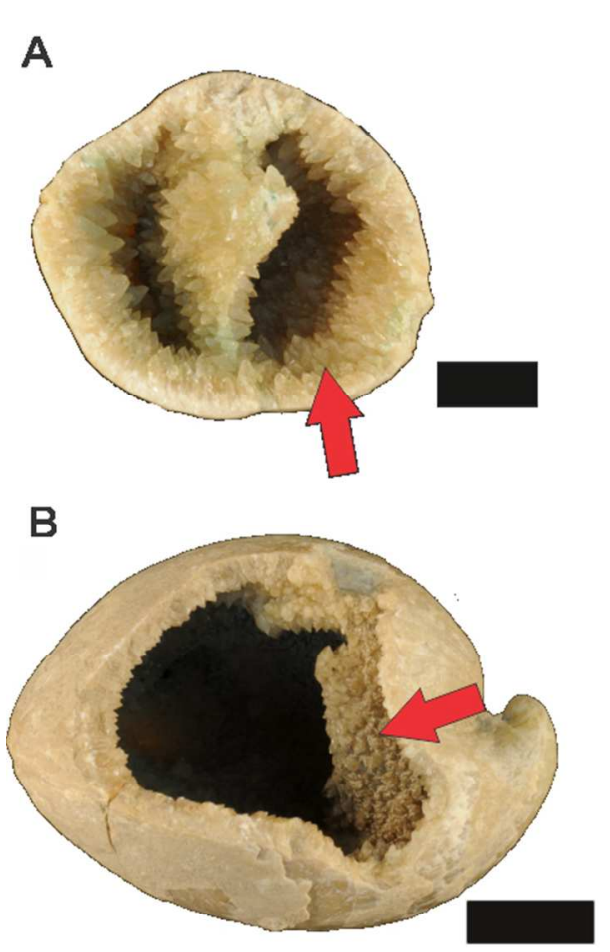

C

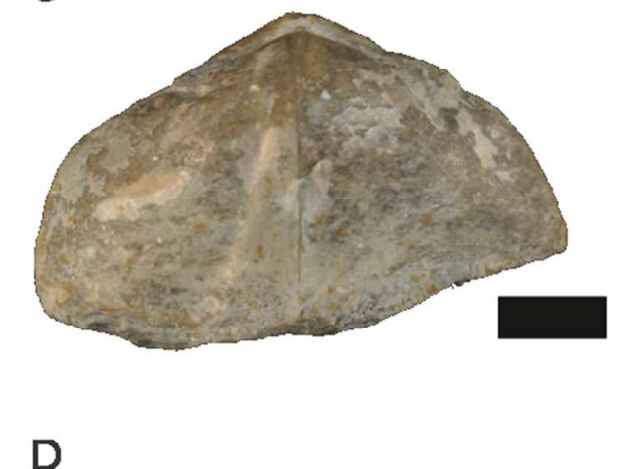

D

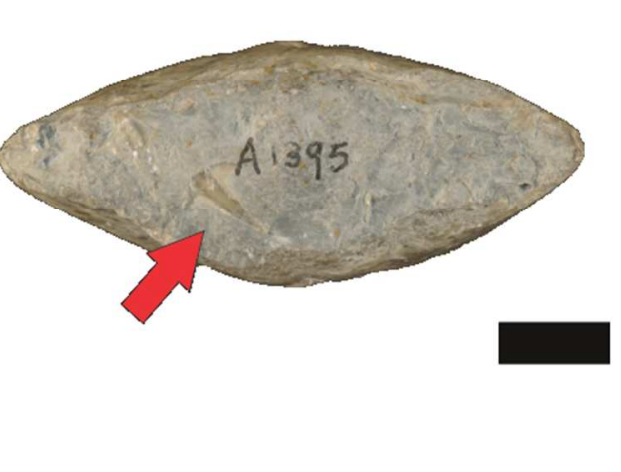

Fig. 4. Differing taphonomies of $P$. septentrionalis $(A / B)$ and $P$. subrectus $(C / D)$. Note the egg-thin shell and isopachous cement filling in $A / B$ and the broken and infilled shell of C/D. Scale bars are $1 \mathrm{~cm}$. Arrows mark the interiors of the shells. Specimen A: ROM 63696, Specimen B: ROM 63697, Specimen C/D: A1395. 

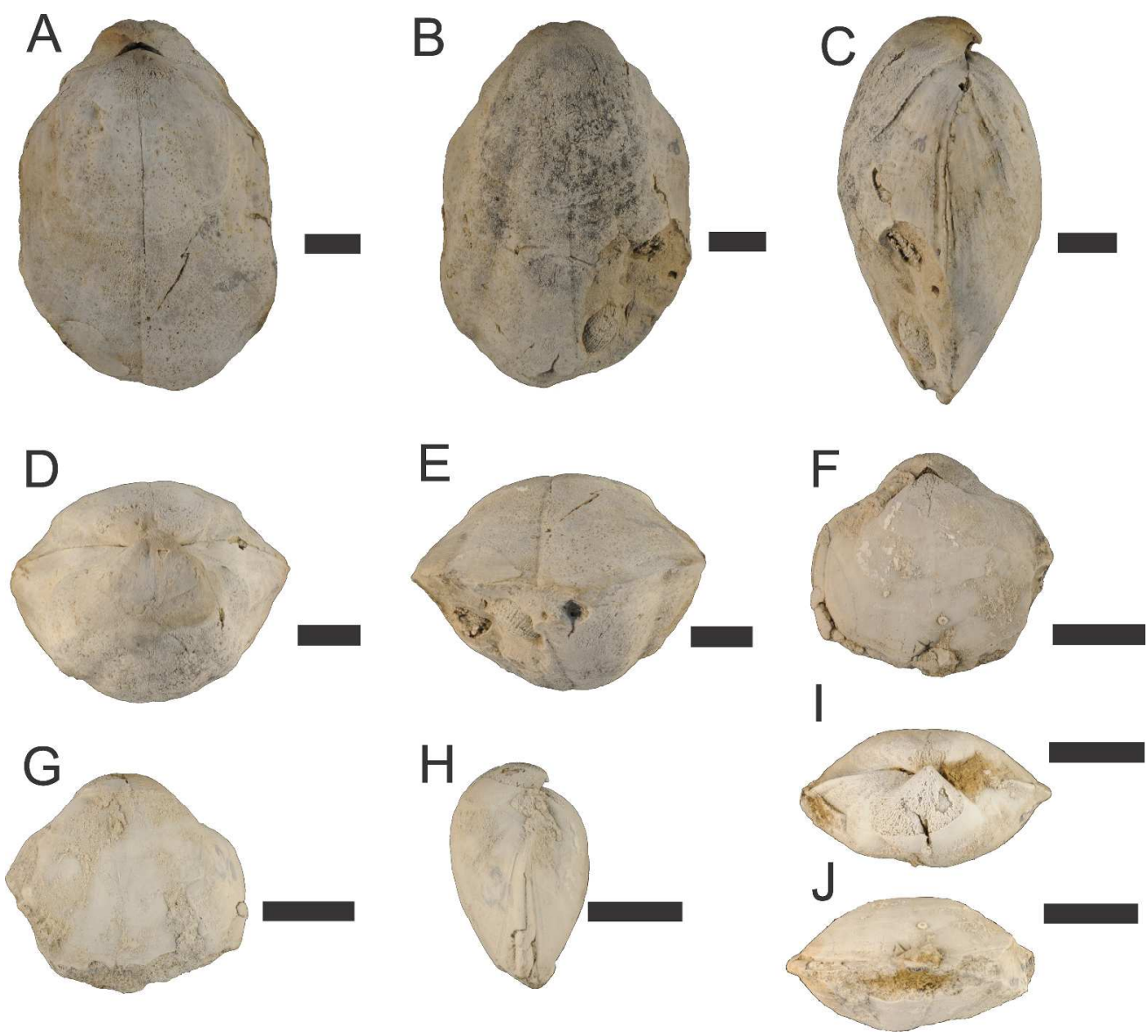

Fig. 5. Pentameroides subrectus, Fossil Hill Formation, Manitoulin Island, Ontario. A-E: Specimen M25-2 dorsal, ventral, lateral, posterior, and anterior views. F-J: Specimen M25-43 dorsal, ventral, lateral, posterior, and anterior views. Scale bars are $1 \mathrm{~cm}$. 

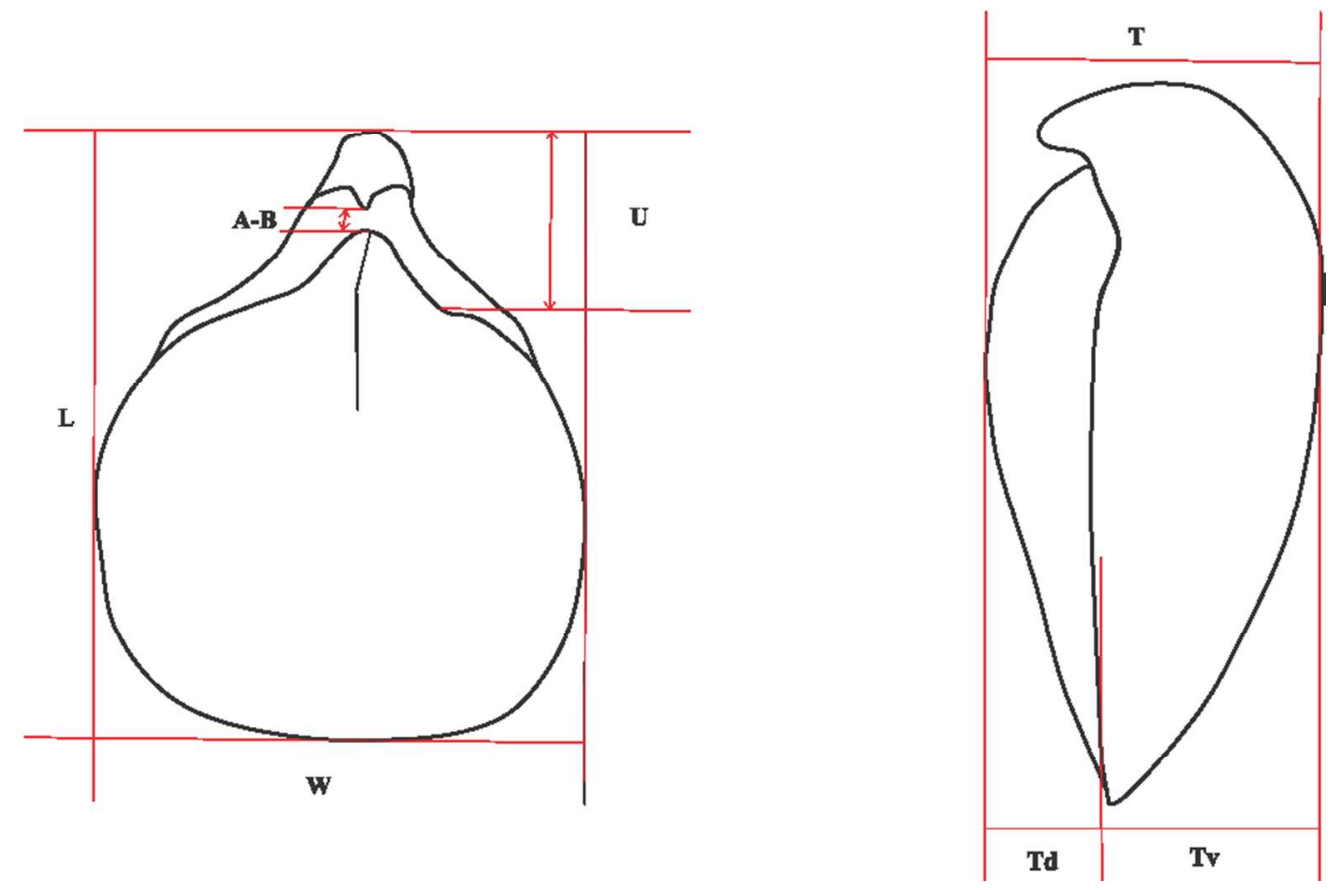

Fig. 6. External morphological characters measured in this study. 


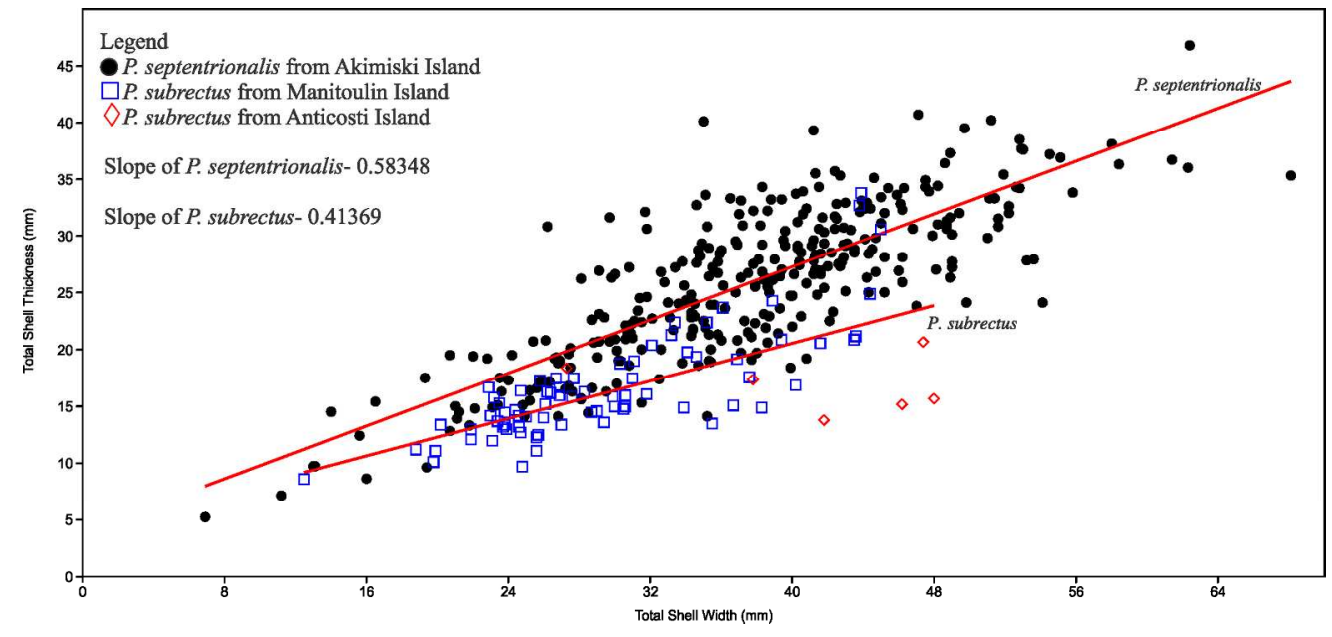

Fig. 7. Plot comparing globosity (total shell width vs total shell thickness) of $P$. septentrionalis and P. subrectus. 


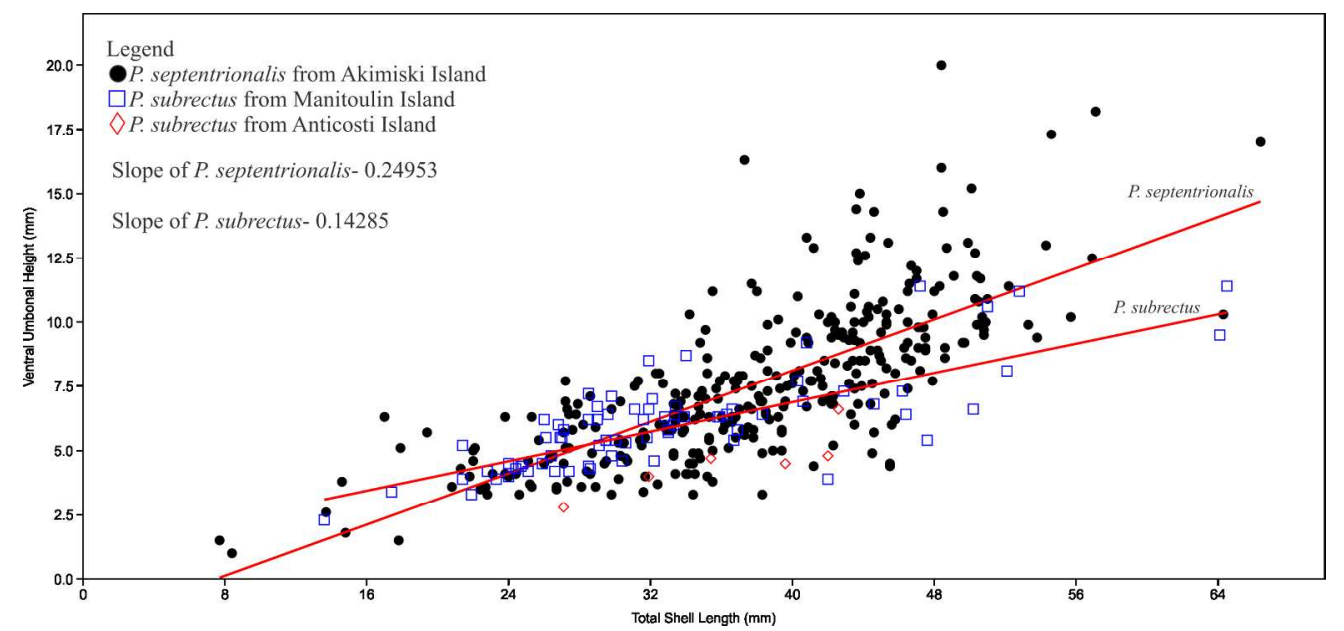

Fig. 8. Plot comparing ventral umbo length to total shell length of P. septentrionalis and P. subrectus. 


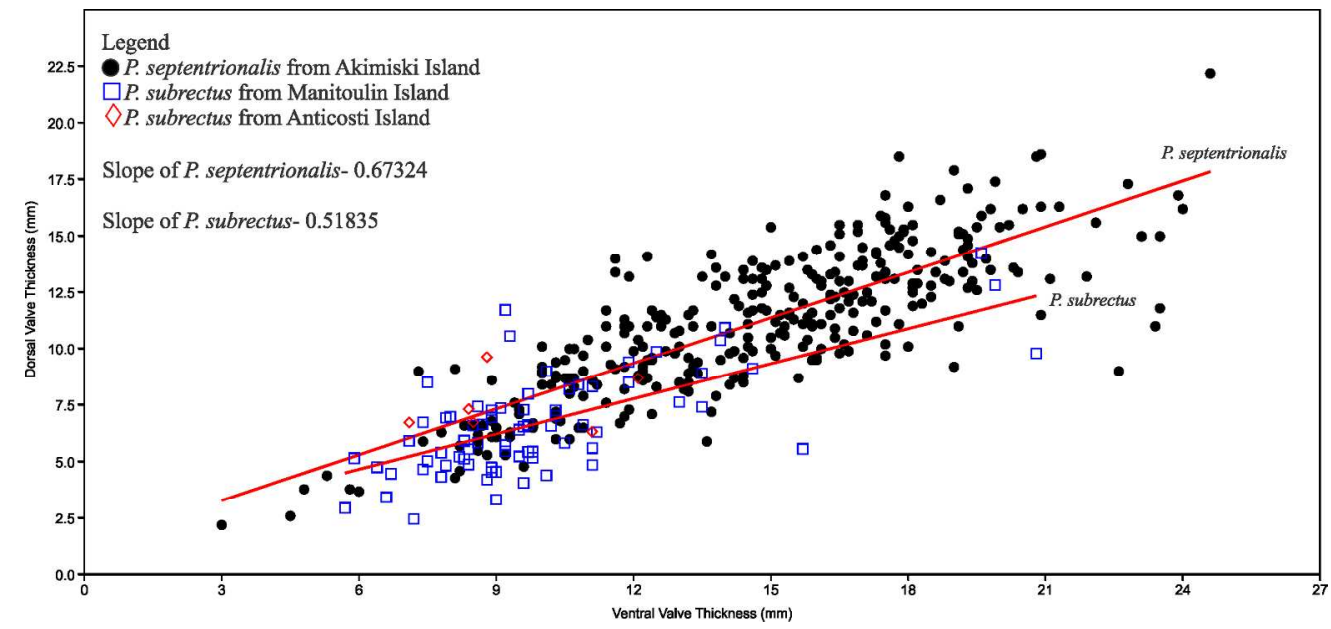

Fig. 9. Plot comparing biconvexity (dorsal valve thickness vs ventral valve thickness) of $P$. septentrionalis and P. subrectus. 


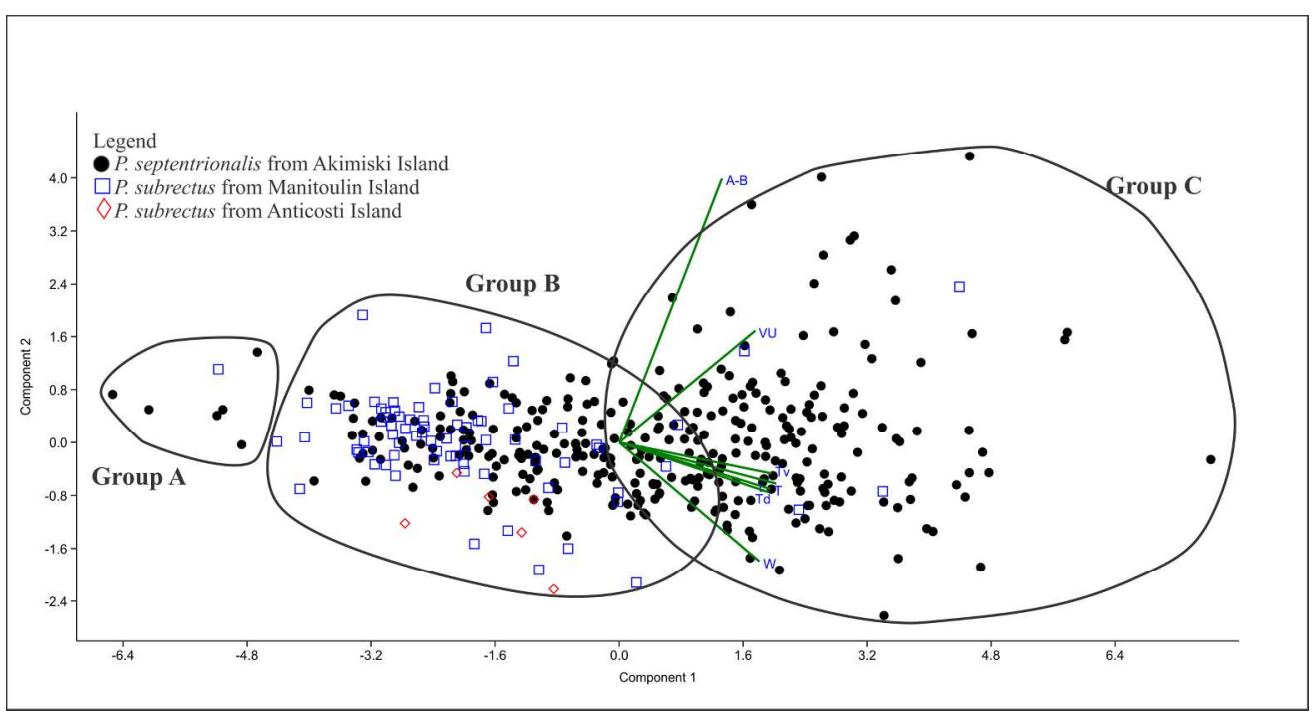

Fig. 10. PCA plot showing distribution of the three collections. Group A: juvenile P. septentrionalis and outlying small P. subrectus from Manitoulin Island; Group B: mid- sized P. septentrionalis and adult P. subrectus; Group C: large sized P. septentrionalis and outlying large P. subrectus from Manitoulin Island. 


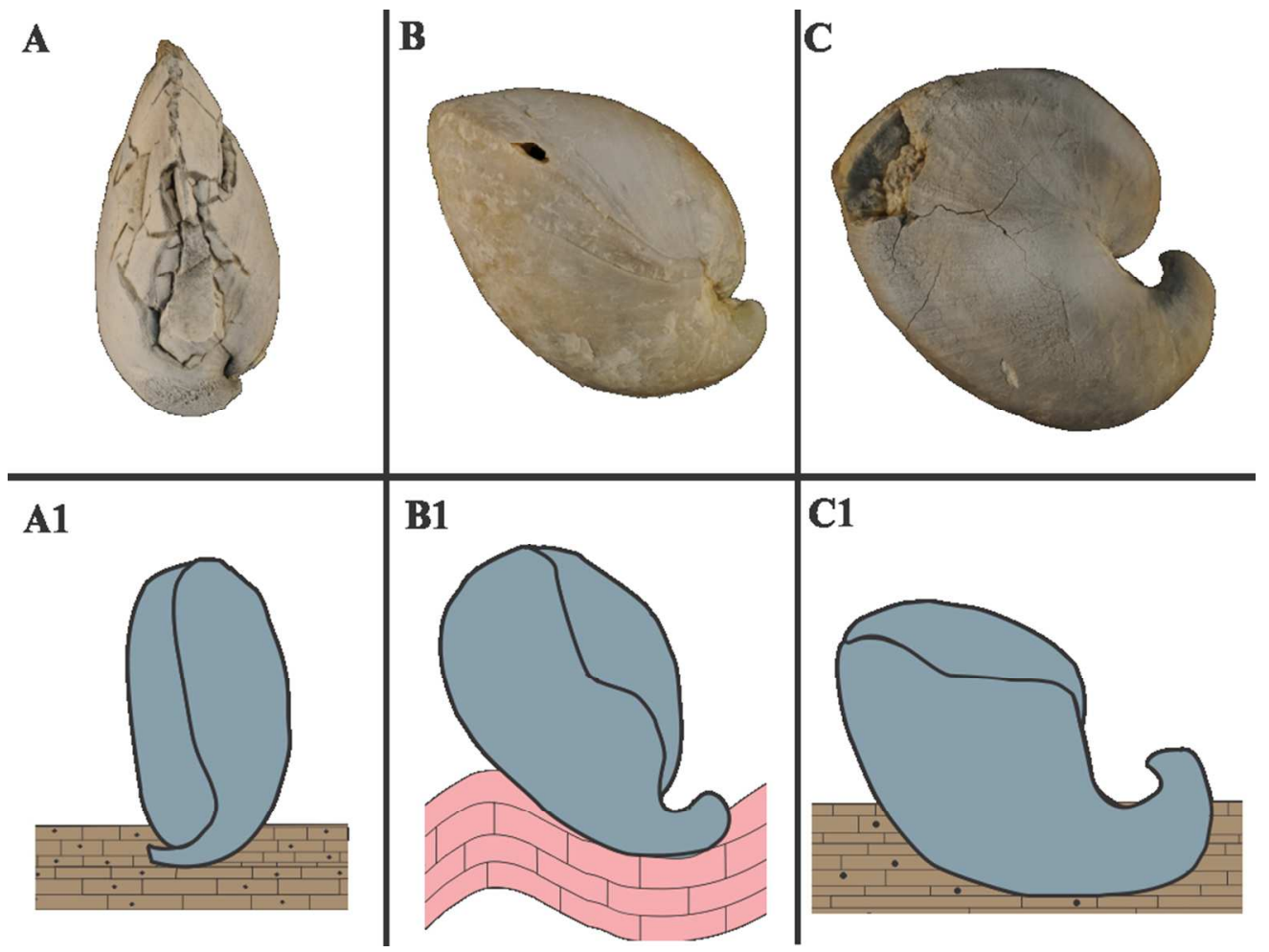

Fig. 11. The interpreted life positions of: $P$. subrectus in high tropical level-bottom environments (A/A1), $P$. septentrionalis in low tropical reefal environments (B/B1), and Harpidium and Sulcipentamerus in equatorial level-bottom environments $(C / C 1)$. Note the transition in life position from vertical $(P$. subrectus) to recumbent ( $P$. septentrionalis and Harpidium/Sulcipentamerus) as latitude decreases. 
A) Low Tropical Hudson Bay Region

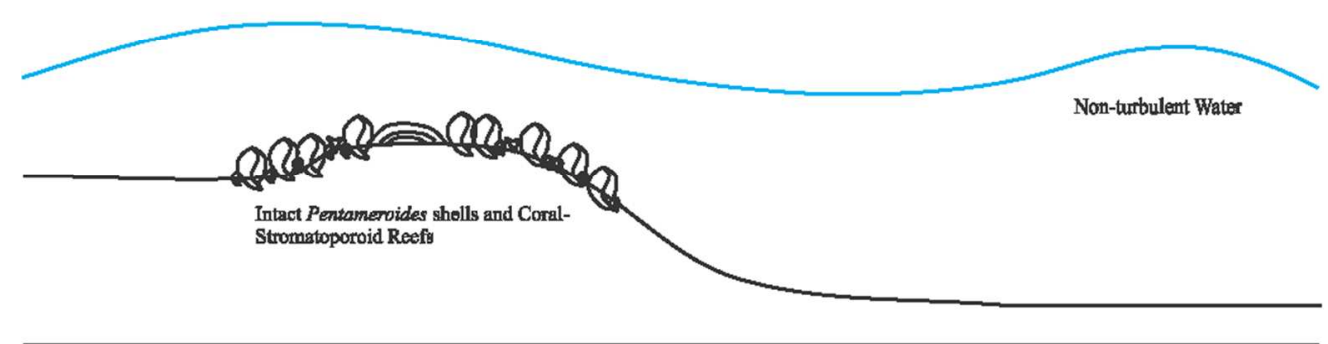

B) High Tropical Michigan/Anticosti Basins

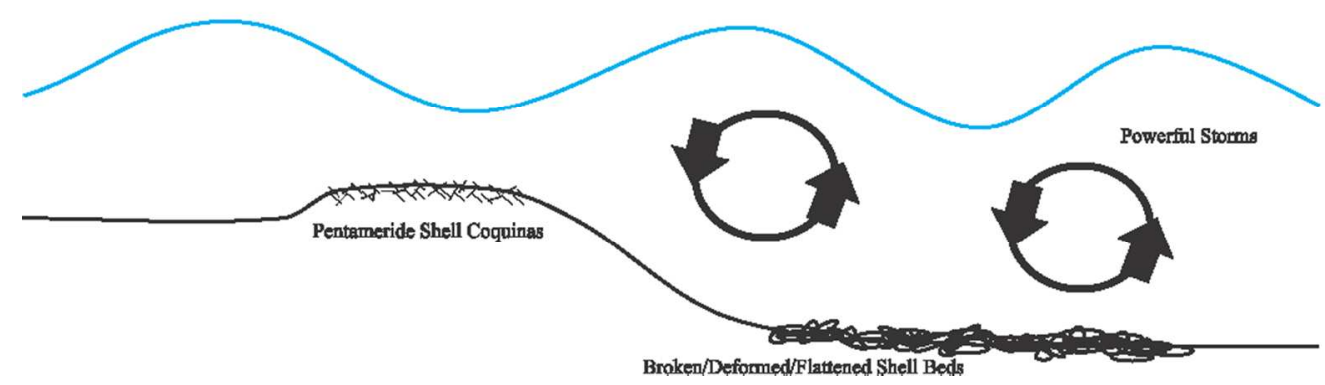

Fig. 12. Comparison between environments of low tropical reef environment and high tropical storm dominated level-bottom communities. Differences in water depth habitation and taphonomy are shown in the reconstructed shell beds. 